\title{
Some Evidence of South European Contacts of the Middle Volga and Kama in the Material Culture of Toretskoe Urban Settlement
}

\author{
Svetlana I. Valiulina ${ }^{1}$ \\ ${ }^{1}$ Kazan (Volga Region) Federal University, Kazan, Russia \\ Correspondence: Svetlana Valiulina, Kazan (Volga Region) Federal University, Kremlyovskaya Street 18, Kazan \\ 420008, Russia. E-mail: svaliulina@inbox.ru
}

Received: April 14, 2015 Accepted: April 20, 2015 Online Published: April 27, 2015

doi:10.5539/jsd.v8n4p292 URL: http://dx.doi.org/10.5539/jsd.v8n4p292

\begin{abstract}
The relevance of the article is determined by insufficient study of the late Middle Ages material culture in the Volga-Kama region and its inclusiveness in Eurasia's culture development. The purpose of this article is to present a whole attribution and historical interpretation of the belt set and an accessories element or a detail of a musical instrument. A complex approach, consisting of comparative-typological and historical-geographical methods is used in the work. The alloy's nature of the non-ferrous metal ware has been identified by a scanning electronic microscope/ X-ray diffraction. The material under consideration reveals a wide geography of similarities within Eurasia that in many cases is caused by the process of intercultural interaction in the late Middle Ages. The study presents technological characteristics of the ware, their origin and possible ways of entering the Volga-Kama region have been determined and the dating has been specified. This article should be of interest to archaeologists and historians of international relations and the late Middle Ages material culture during their research and educational process.
\end{abstract}

Keywords: Middle Volga and Kama, Kazan Khanate, intercultural interaction, material culture, belt set, copper-based alloys

\section{Introduction}

The relevance of the study lies in the fact that it for the first time presents the proof of South European contacts of Toretskoe settlement. The significant site of 250000 sq. metres situated in the central part of Western Kama (Alexeyevsky District, Republic of Tatarstan) has been studied by Bilyar expedition of Kazan University carried out by the author since 1998. Owing to the excavation, a previously unknown town has been discovered - the centre of metallurgical and metal-working handicraft and also of international trade of the XV century. A rich import collection, e.g. China porcelain, amber, Crimean glazed pottery, Syrian glass, Chorasmian faience and such trade instruments as scales, weights, Hanseatic commercial stamps, more than 400 coins indicates the scope of the trade (Valiulina, 2008; Valiulina, 2010). Kazan Khanate didn't have its own mint that is why the late Horde coins of the first quarter of the XV century circulated for some time. However, there was some special Russian money as well, for example, the money of The Grand Duke Vasily the Dark (1425-1462).

The significant site is one-layered, apparently it didn't exist long, in the XV century, or from the end of the XIV to the XV century, and it was lost after a military attack at the end of the XV century. Probably, the attackers were the Nogais, as after the Golden Horde's downfall there was no one to oppose them in the Volga region. By the end of the XV century the Nogais came up to the Kama's estuary, which has been proved not only by the written sources but also by almost a complete absence of settlement sites of the Kazan Khanate times in the Central Zakamie region (Fakhrutdinov, 1975; Archaeological monuments, 1990).

All the excavation materials and the data of stratigraphy indicate that it was an unexpected, violent and ruthless attack on Toretskoe. The site is characterized by the abundance of the material, its being preserved and the location in the objects - everything stayed in their places, covered by the layer of the fire and destruction, in which there are some singular human bones and unburied skeletons. In addition, hidden treasures and the so-called "mass graves" (a collective burial performed in a hurry, without observance of rituals) are an expressive illustration of the last page of the town's history. Only women and children lie in these burials - all with the traces of fatal injuries. The mass graves, as well as hidden treasures, are situated on the residential facilities and yards of the settlement, mostly in the loose golden filling of the furnace pot holes. At present nine 
treasures - money (the largest one contained 243 silver coins), things and instruments, have been found on the investigated area (about 5000 sq. metres). One of these treasures has been discovered in the central part of the site (dig №1) during the investigation of the pot hole in residential facility №1. The building had a rectangular form of $620 \times 430 \mathrm{~cm}$ of frame-and-pillar design on the sun-dried earth brick socle with clayed earth floor. Two cob brick furnaces were situated in the northern corner of the house (the corners were oriented at the four cardinal directions). On the floor level there was only one burning spot and the broken bricks from one furnace left, while the other was erected in an oval pit that was $80 \mathrm{~cm}$ deep from the floor surface. Its being preserved lets us imagine the reconstruction of it (the laying, the fragment of the stone slab, the orifice are preserved).The stairs from the floor level led to the furnace. The ash pit was situated in front of it $(80 \mathrm{x} 85 \mathrm{~cm})$ and several belongings, that were intentionally hidden, have been found in it (Valiulina, 2001). The treasure consisted of both high status and everyday objects and instruments, such as the iron ones: a lock, an ax, knives, a spoon player; a Khorezmian earthenware jug with a stamped ornament, stone grinding hones, a copper cup of scales, and a set of bone objects: handles, a pounder-pestle and a bludgeon made of elk's horn with an iron centre. Besides the bludgeon, a high status possession, was of course, the belt set.

\section{Materials and Methods}

The article introduces some materials of new excavations of Toretskoe settlement in Alexeyevsky District of Tatarstan. Figure 1: the complex of a belt set, the accessories element or a detail of a musical instrument. A complex approach, consisting of comparative-typological and historical-geographical methods is used in the work. The alloy's nature of the non-ferrous metal ware has been identified by a scanning electronic microscope/ X-ray diffraction (analyst Trifonov A.A.)

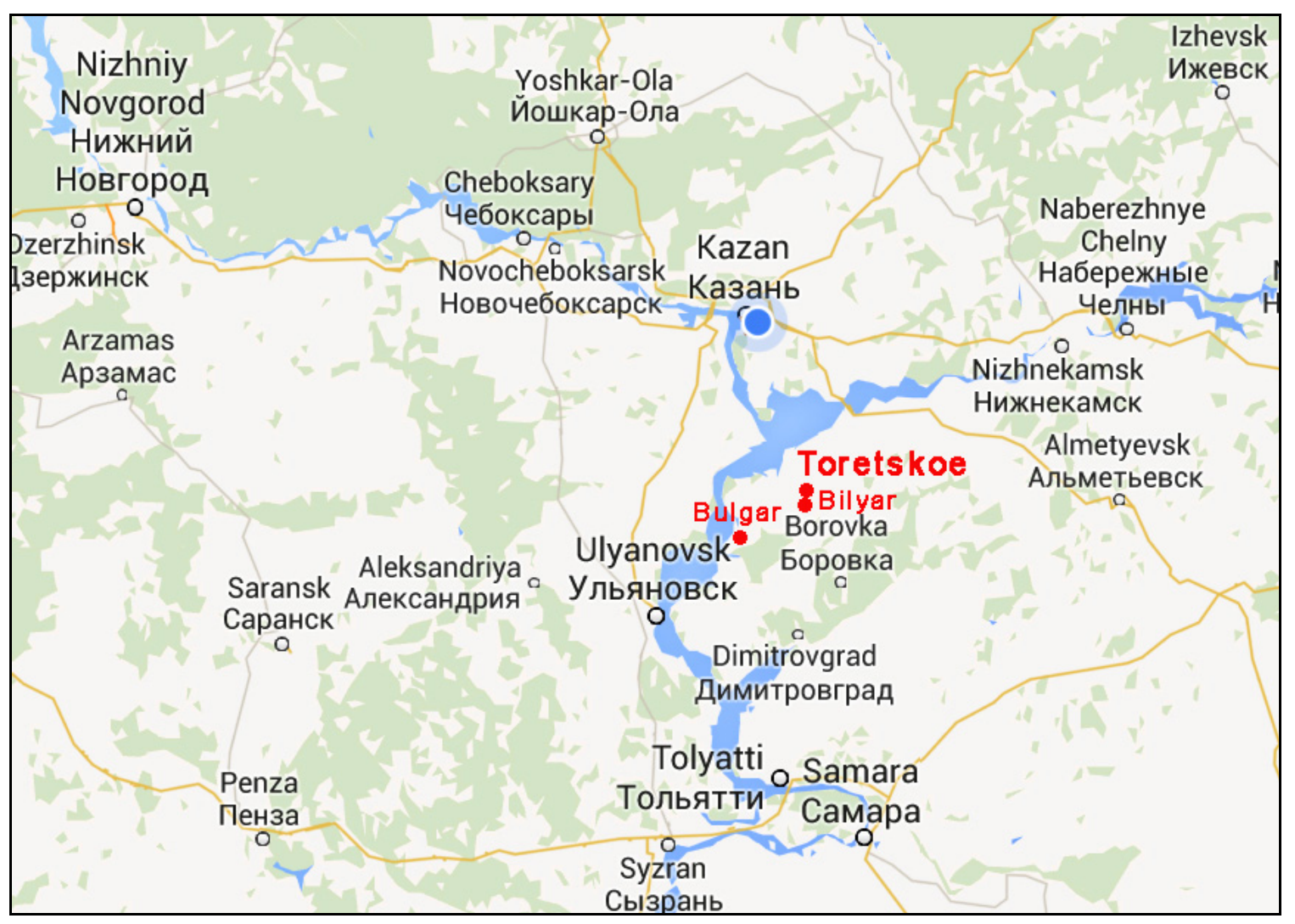

Figure 1. Toretskoe settlement (Republic of Tatarstan): Location map

\section{Results and Discussions}

\subsection{The Belt Set}

The belt set includes iron details - a buckle and a narrow clip, as well as bronze - a rectangular clip of two $26 \times 30 \mathrm{~mm}$ plates clamped with four pegs on the corners and tiny mounts -3 specimens $20 \times 7 \mathrm{~mm}$. (one was destroyed when it was discovered). The latter have a long shape with trefoils (lilies?) at the ends and a hexagonal convexed rosette in the centre. Figure 2, were made from multicomponent brass by casting (Table 1, analysis 1). 


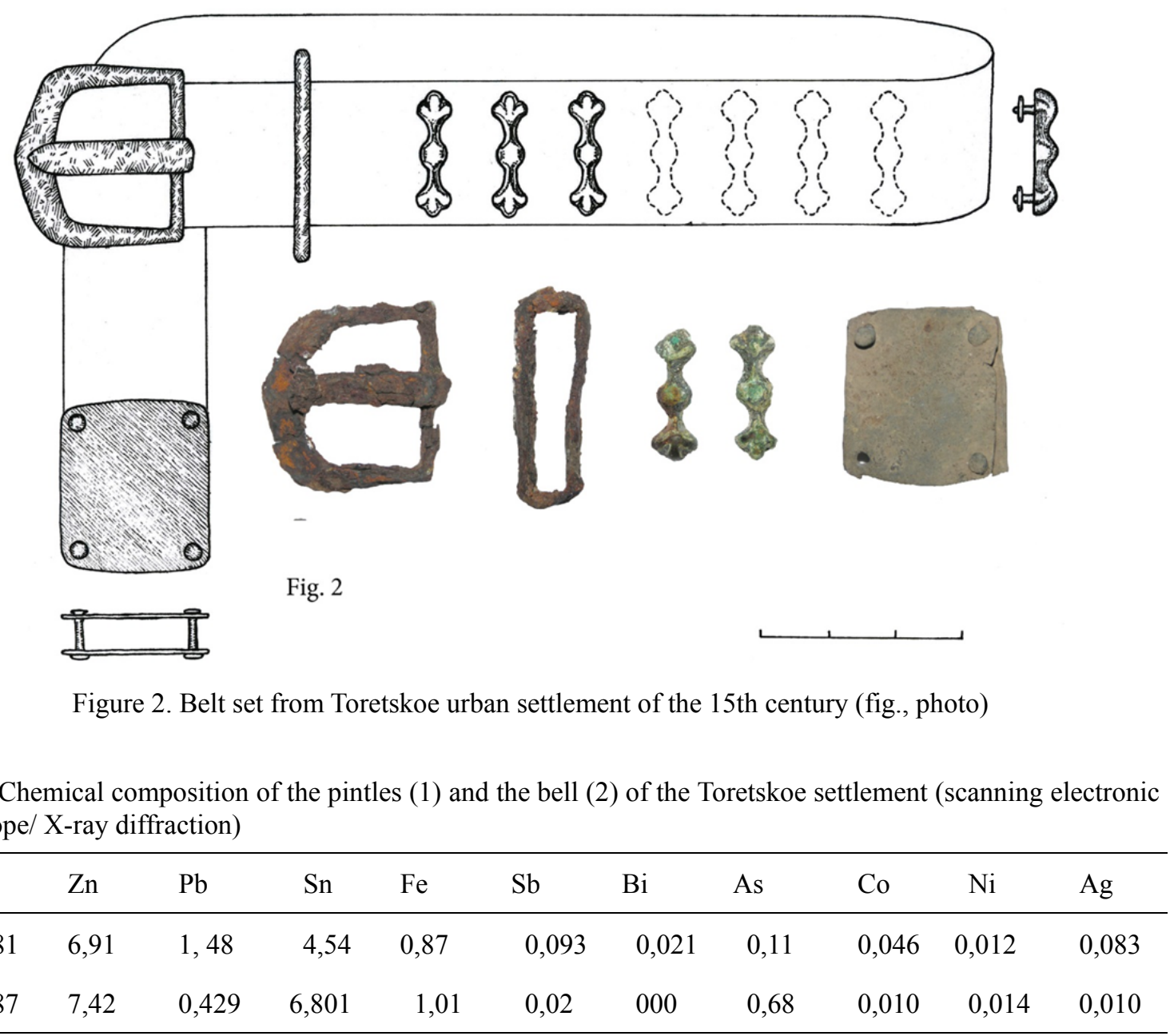

Table 1. Chemical composition of the pintles (1) and the bell (2) of the Toretskoe settlement (scanning electronic microscope/ X-ray diffraction)

\begin{tabular}{cccccccccccc}
\hline & $\mathrm{Cu}$ & $\mathrm{Zn}$ & $\mathrm{Pb}$ & $\mathrm{Sn}$ & $\mathrm{Fe}$ & $\mathrm{Sb}$ & $\mathrm{Bi}$ & $\mathrm{As}$ & $\mathrm{Co}$ & $\mathrm{Ni}$ & $\mathrm{Ag}$ \\
\hline 1 & 85,81 & 6,91 & 1,48 & 4,54 & 0,87 & 0,093 & 0,021 & 0,11 & 0,046 & 0,012 & 0,083 \\
2 & 80,87 & 7,42 & 0,429 & 6,801 & 1,01 & 0,02 & 000 & 0,68 & 0,010 & 0,014 & 0,010 \\
\hline
\end{tabular}

The similar by shape and size bronze mounts were found in Old Orhei, Fig. 6. (Barnea\&Reaboi, 1998), in the Cossack village Belorechenskaya of Kuban (Veselovsky, 1898) and in Chembalo fortress of the Crimea, in the layer of the XV century (Adaksina et al, 2004), collection inventory \# 145, in which besides the mount there is also a typical ornamental buckle; though they were excavated from different places, they might have belonged to one and the same belt.

Figures 3,4. The list of analogies of Toretsk mounts, in the form of a stick with different versions of edge decoration, includes the mounts from Dumbarton Oaks's collection (Ross, 2005; Lango\&Polgar. 2009), the finds in Esztergom-Sendiri, Hungary, in Netsallash II's burial ground; in the Santa Reparta basilica's burial in Florence. Fig.5, and on the waist of Count Eckerhard's statue in Naumburg, Germany (Lango\&Polgar. 2009); single ware from different places in Bulgaria (Pavlova, 2011). 


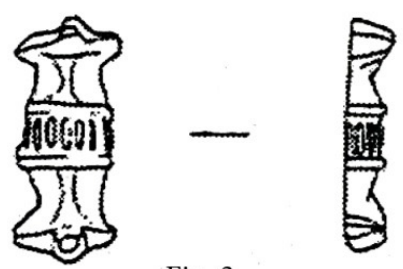

Fig. 3

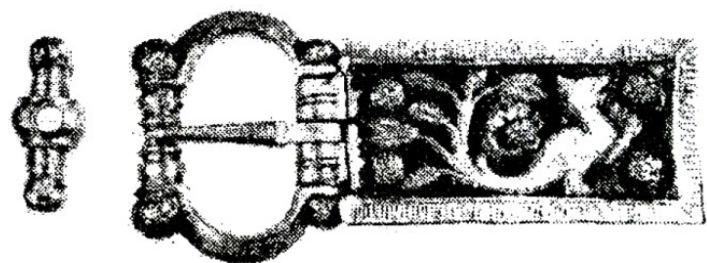

Fig. 5

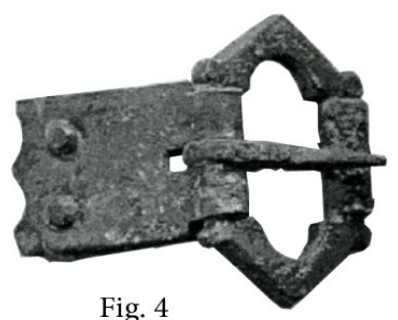

Fig. 4

Figure 3. Belt mount from the Chembalo fortress, Crimea found in the $15^{\text {th }}$ century layer (Adaksina, Kirilko, Mytz, 2004)

Figure 4. Buckle from the Chembalo fortress, Crimea found in the $15^{\text {th }}$ century layer (Adaksina, Kirilko, Mytz, 2004)

Figure 5. Belt mount and buckle from the burial ground no. 82 of the basilica Santa Reparata in Florence (Lango \& Polgar, 2009)

Figure 6. Belt mount from Old Orhei (Barnea \& Reaboi, 1998)

These objects refer to a circle of exquisite gold and silver sets, such as the sets from Simferopol treasure, Figure 7 (Malm, 1989), from the collection of the British Museum, Figure 8; (Anadolu Medeniyetleri, 1983; Anatolian Civilisations, 1983), from Nikopol and Lozents in the exposition of the Archaeological Museum in Sofia, the Historical Museum in Sofia, the museum of Varna and many others.

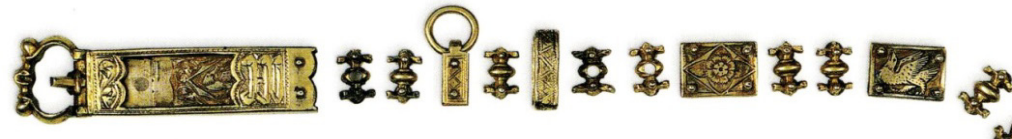

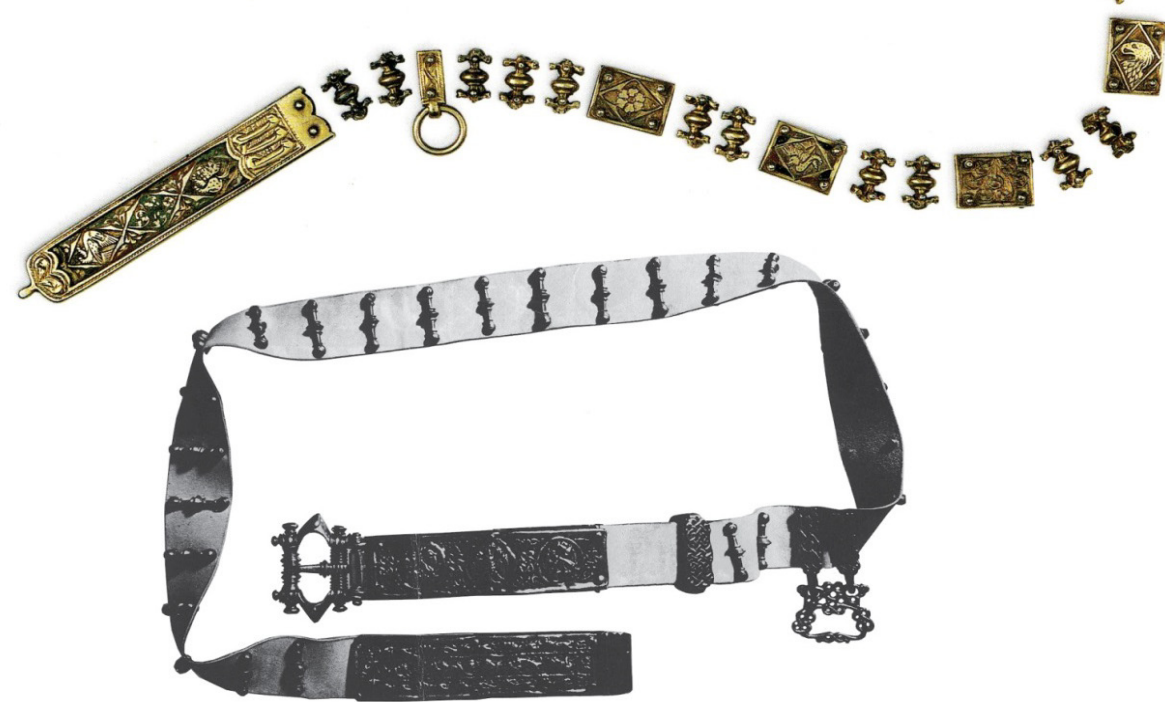

Figure 7. The belt from Simferopol treasure trove (Crimea). First half of the 14th century. State Historical Museum, Moscow (Malm, 1989)

Figure 8. Belt from Turkey, 1220s. British Museum (Anadolu Medeniyetleri, 1983) 
The dress aristocratic belts of the XIII-XIV centuries decorated by graceful figure-shaped buckles and mounts of several types, among which the most expressive were in the form of a double lily and tiny relief sticks or "symmetric balusters"(with M.G. Kramarovsky) have an extensive historiography nowadays. I. Fingerlin's work is classical which accomplishes the systematization of materials of European monuments and presents a typographical table of lyre buckles. As a result, the author drew a conclusion that this ware had appeared earlier in Western Europe and existed since the 13 until the middle of the 14 centuriy (Fingerlin, 1971). However, the new discoveries of the following four decades let the scholars extend the time of the existence of such complexes, including the 15 century (Ross, 2005; Lango\&Polgar, 2009; Pavlova, 2011).

A considerable number of publications introduce into science new finds and they present analogies reviews, therefore, the number of sources grows and geography of finds expands from Great Britain to Novgorod, the Urals and Syria. The publication of the materials found during excavations in situ, stratified and provided with archaeological and historical context, has a special significance. One of these latest publications is about two belt sets of the XIV century received from the necropolis in Dorestad (Atanasov, 2011).

Analyzing the belt's details of the Dumbarton-Oksky's collection of the Institute of Byzantine Studies, Harvard University aimed to identify their dating and origin, Lango and Polgar give a lot of examples of analogies, first of all, in Central Europe, the Balkans, the Eastern European steppes and the Mediterranean area where the ware circulated in the XIII-XV centuries and were presented by a greater number than in the East, and were made not only of precious metals, but bronze as well.

V. Pavlova has presented a more detailed summary of these finds, judging by the sites of Bulgaria and neighbouring territories. There are almost absolute analogies to Toretsk specimens, Fig. 9., not only in archaeological materials, but also in church wall paitings of the XIV- the second half of the XV centuries. The rare written documents, miniatures and wall paintings in the churches and the sculptures indicate that these types of belt decoration became popular in Europe especially in Balkans and existed in the XIII-XV centures (Pavlova, 2011). Analyzing the belt set of the end of the XIV century, with the mixture of mounts of two types, round and in the shape of a "double lily", found near the Kichevo village and admitted to the Archaeological Museum of Varna, the author, judging by the finds of casting moulds and semi-completed castings, came to the conclusion that such decorations had been made in various places of Bulgaria. Besides, the possibility of craftsmen from Dubrovnik having worked in Tyrnovo is not excluded, in the same way as it took place at the court of Serbian rulers, in Bosnia, Venice, Hungary and at the Duke of Ferrara's court (Pavlova, 2011).
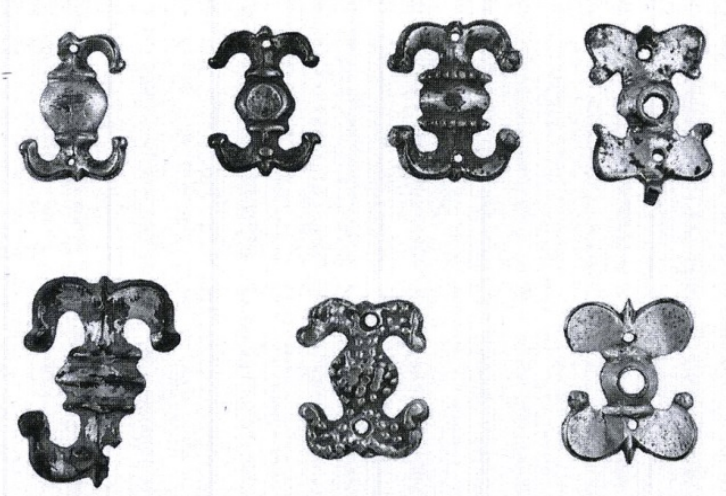
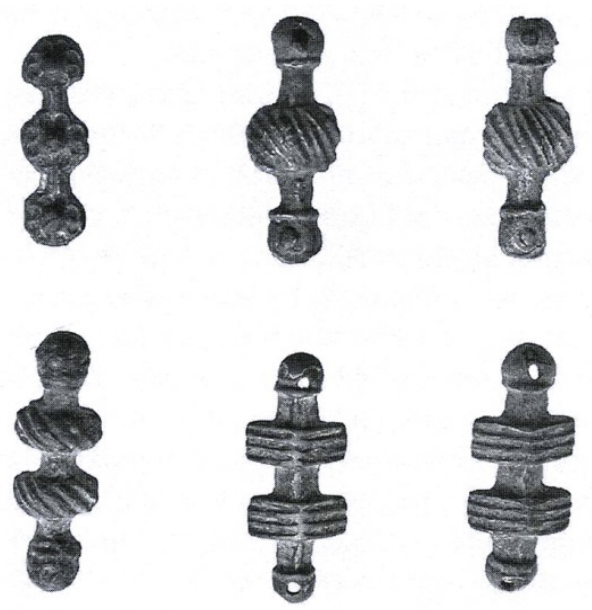

Figure 9. Belt mounts - separate items from different sites in Bulgaria, $13^{\text {th }}-15^{\text {th }}$ centuries (Pavlova, 2011)

M.G. Kramarovsky thinks that the gold and silver sets with the mounts like "tiny symmetric balusters" was made in the jeweller's workshops of Southern Europe from the Central Mediterranean to the Crimea, where Latin metal workers worked in Kaffe (Kramarovsky, 2011).

These belt sets are well-known mainly in steppe zones of Eastern Europe (Veselovsky, 1898; Kramarovsky, 1985, Otroshenko, Rassamakin, 1986), and very rarely get farther to the north. Thus, the belt mounts of a shape similar to the Varna belt design, decorated the leather belt from Novgorod of the XIII-XIV centuries (Gorelik, 2008).

As far as the background of these belt sets is concerned, the prototypes had already been found in Early 
Byzantine sites. For example, the Christian Salon bronze belt mounts in Archaeological Museum, Split, Figure 10 , of the second half of the IV- first half of the V centuries. A totally different buckle's look - simple, squared with the bifid tongues and tracery flap; two types of mounts (tiny, narrow and larger) - characterizes these two sets (Buljevic, Ivcevic, Mardesic, Visic-Ljubic, 1995). Both types of mounts belong to the Early Medieval ware decorated in so-called "double fish's tail" style. As a result of its development during centuries, this style led to the "double lily" style in the XIII century. Thereupon, Salona belt mounts are similar to narrow set mounts of the beginning of the XIII century from Syria in the Mayer Museum of Jerusalem; currently it is one of the earliest complexes like this (Parani, 2003), along with the Anatolian one from the British Musem (Anadolu Medeniyetleri, 1983).

Taking into account the other analogies of the Byzantine sites, mentioned by Parani, the belts from Salona, in our opinion, are the confirmation of the hypothesis that initially the buckles and mounts of dress belts of XIII-XV centuries have absolutely different origins - the mounts were developed by the late antique and early Byzantine artistic traditions of Southern Europe, or perhaps by the Eastern Byzantine provinces and the figured frames appeared later, not earlier than in the XIII century in Western Europe and after became popular in the Mediterranean area, where the whole ensemble of a belt set came into existence. Some authors see the significant role of intercultural interaction of the High Middle Ages in Eurasia and first of all, the crusader's activity (Lango\&Polgar, 2009).

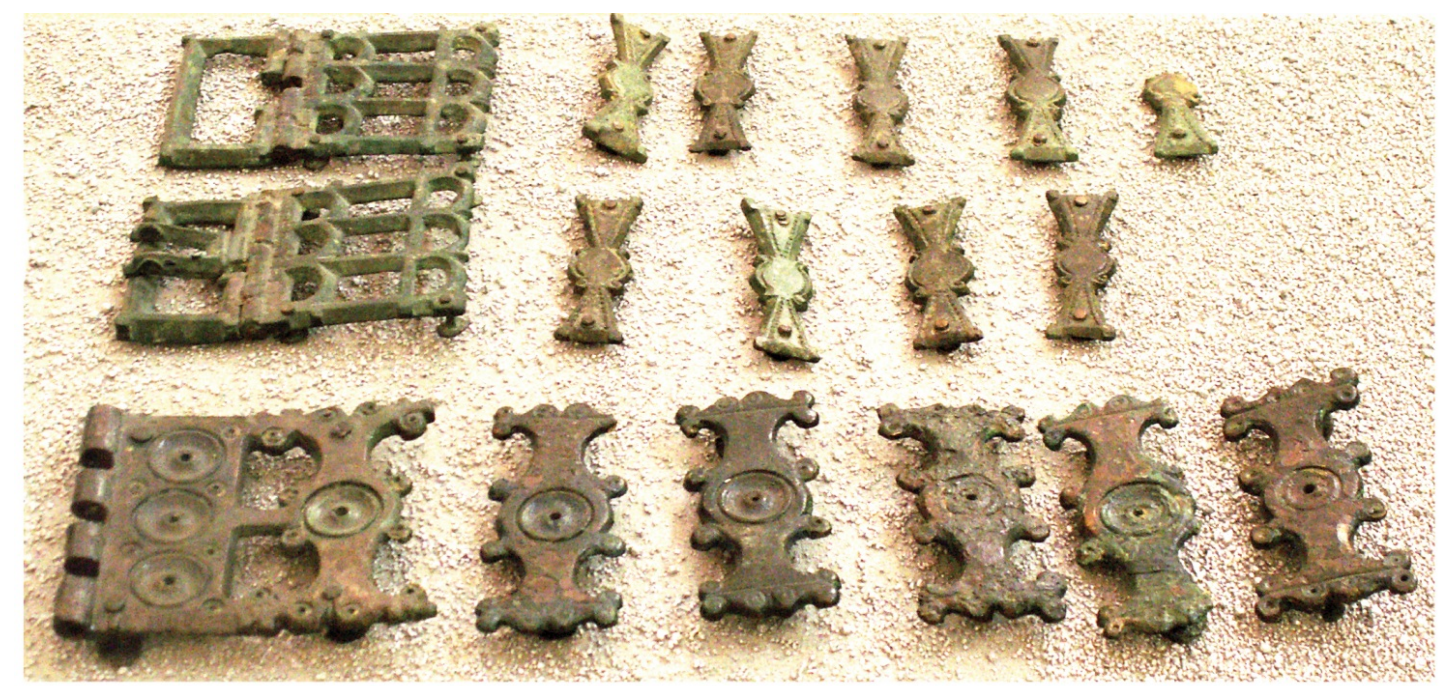

Figure 10. Belt sets from Salona, end of the $4^{\text {th }}-5^{\text {th }}$ centuries (Archaeological Museum of Split, photo by author)

After I. Fingerlin the researchers consider lyre-shaped buckles belts as a unique manifestation of aristocratic fashion not associating them with any ethnic group in the late Medieval Europe (Fingerlin, 1971; Pavlova, 2011; Atanasov, 2011). Apparently, these belt sets were made in many European craft centers, and sold at different prices at numerous markets and international fairs depending on the material and workmanship. And after, as goods, presents or as a part of a foreigner's outfit they were delivered to such remote places as Toretskoe. Undoubtedly, not only further development of typological analysis as Atanasov considers (Atanasov, 2011), but also the data about the character of the alloy of things - the knowledge of the chemical composition of the material will in future promote establishment of regional handicraft traditions in making such wonderful pieces of art.

The belt mounts of Toretskoe are certainly an import and belong to late simplified group of ware the most remote from the centre of the industry. There is no complete kit of the parts in Toretsky set. The stylistic unanimity has been infringed - there is an iron buckle instead of a lyre bronze one, it has only the same size, corresponding to the width of the belt. This ware cannot belong to Volga-Kama region because of the alloy's nature - a multicomponent brass, the material which Middle-Volga craftsmen didn't work with (Valiullina and Zaitseva, 2011). It might be supposed that the Toretsky belt set is an evidence of the final of the lyre buckle sets' existence history. 


\subsection{The Bell}

There is one more find on the Toretskoe settlement which acts as manifestation of the broad fashion on a detail of a suit and life within Eurasia in the late Middle Ages. That is a bell. Figure 11a, round and flat at the top and the bottom, with the diameter of $2 \mathrm{~cm}$ and height of 1,6 $\mathrm{cm}$ ( only the bottom half is preserved), was made from a copper-based alloy - triple brass, Table 1, analysis 2 . The compositions of the bell and the above-considered mounts are very similar, belonging to one type of alloy.

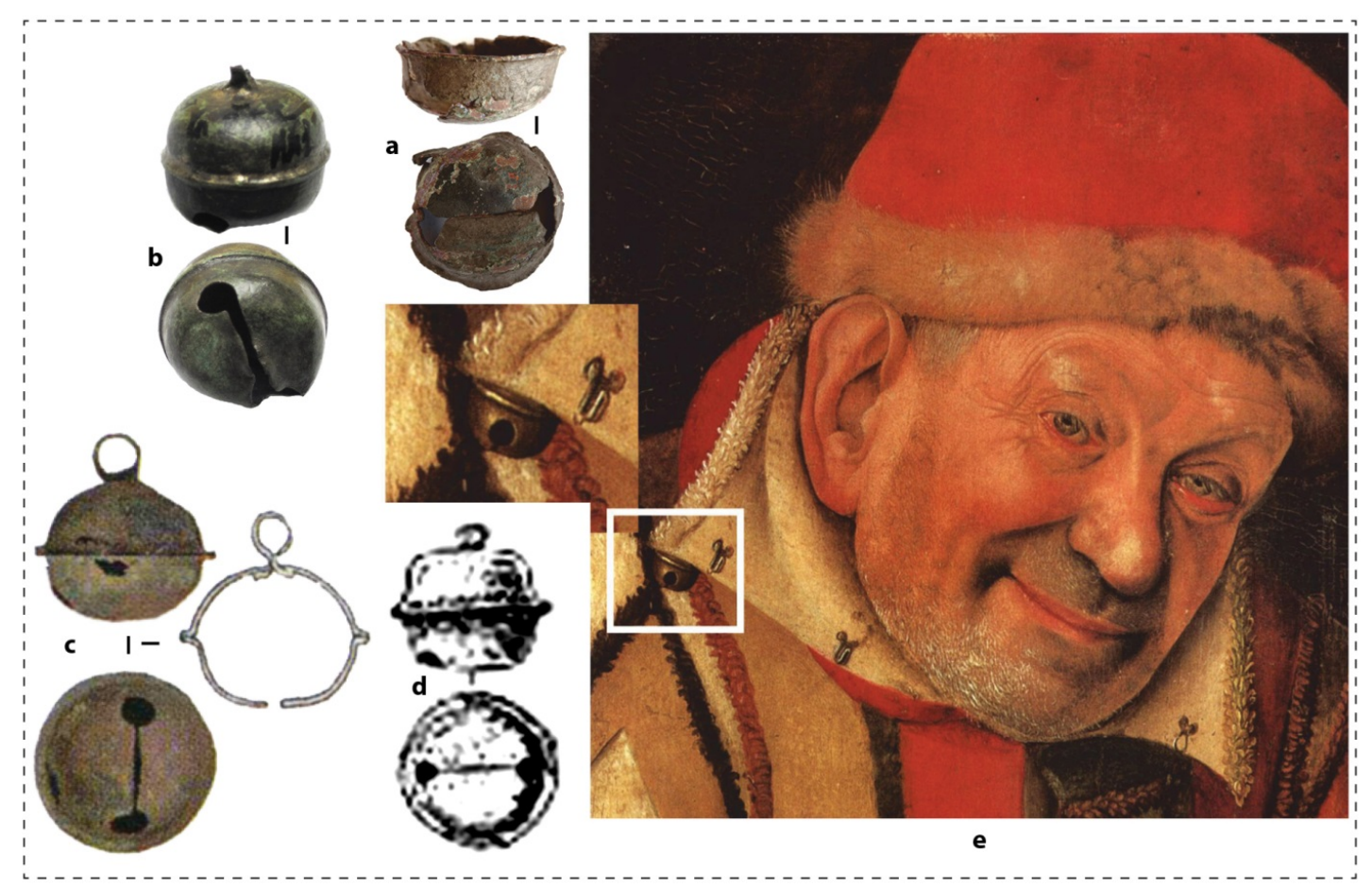

Figure 11. Bells

- $\quad \mathrm{a}$ - Toretskoe settlement

- $\quad b-$ City of Bulgar

- c- Gnalic, Croatia (Schick, 2006)

- d - Endyrsk burial ground, West Siberia (Zykov\&Koksharov, 2001)

- $\quad$ e - Bell on the costume of Gonella, Court Dwarf of the Duke of Ferrara (Jean Fouquet, 1445).

The halves of these bells were pressed or stamped from a metal sheet, but for all that, on the outer edge of each part the horizontal sides remained and these halves were knitted together. The bell had a linear cut at the bottom that came to the end with two rounded holes for better sound. An eyelet shoud have been soldered above, it used to be made from the metal band the ends of which were inserted into the slit of the upper half and unbended to different sides then the slit was soldered up. There was supposed to be a piece of metal or a pebble inside the bell (Zykov\&Koksharov, 2011), this "tongue"or "beater" is very rarely preserved and one could judge about its existence by the traces of rust (Schick, 2006).

The barrel-shaped bells in contrast with the globe-shaped ones are rarely found in East European significant sites - Bolgar. Fig.11b, there are 18 globe-shaped bells for only 2 barrel-shaped ones (Type B-IV-I); the latest find originates from dig №179 of 2013 (the instructor is Koval V.), which investigated the market in the centre of the town. At least, two specimens made of multicomponent brass are known in Pskov (Koroleva, 1996). In Novgorod the barrel-shaped bells belong to the fourth bell type being soldered by two halves (Ryndina, 1963), in the layer of the first half and the middle of the XIII century -2 pieces, XIV century - 10 pieces (Povetkin ,2008). This ware has been found in Bokatash settlement in the Crimea (Kramarovsky\&Gukin, 2004, 2006) and in Kaffe - as reported by Bocharov. Not all the finds can be strictly dated: in Bolgar the bell is a raising material, in Pskov it was published as a result of analytical selection of the X-XVI centuries, in Bokatash settlement it refers to XIII-XIV centuries, in Kaffe it dates back to the second half of the XV century. 
The barrel-shaped bells are represented extensively in the sites of taiga zone in Noth-Western Siberia, Figure 11. Eleven bells have been found in an installation of XV-XVI centuries in Amder and on the Endyr burial. Zykov and Koksharov give the examples of other significant sites of the region where this ware was well-known. The authors come to the conclusion that "the barrel-shaped bells, which were the development of the globe-shaped ones, occurred later than in the first half of the XV century. In Western Siberia they had existed until the first half of XVII (Zykov\&Koksharov, 2001).

The portrait of Gonella, the court dwarf of Ferrara Duke Leonello de Este, painted by Jean Fouquet in 1445 (Vienna Museum) appeared to be some kind of help in the searching of Toretsky bell's analogies. The artist created an amazingly picturesque work that conveyed the mood, physiognomic features and the suit details of the model, such as a texture of fabric, fur, tape, including the bronze barrel-shaped bell sewn to the right collar's lapel (Fig, $11 \mathrm{~d}$ ).

Similar bells are well-known in archaeological sites of Central and Southern Europe, they were classified and related to type D1 by Konrad Spindler (Spindler, 2003). The researchers consider the finds from Switzerland, Austria (Tyrol), Croatia as parts of the musical instruments, the same as in Novgorod (Povetkin, 2008), and also as a decoration, including the sound one, of the sledge, some other uses are admitted as well. The considerable number of the barrel-shaped bells with sides originate from a "closed" complex - the Venetian merchant ship which sank near the Gnalic island in the Adriatic sea, near Croatia's coast in the second half of the XVI century. Fig. 11b. The bells from the ship are similar to East European and Siberian findings by their size, proportions and technique of their work. But some specimens have the printed signs of the master or trader and a lower half was stamped with a "double lily" very seldom. One bell was defective and everything was made of non-ferrous metal, the composition wasn't analysed (Schick, 2006). According to the geography of finds, such bells became popular from Siberia to Spain in late Middle Ages, after America's discovery they crossed the ocean, which was proved by some finds of XVI-XVII centuries in an administrative centre Santa Fe, Argentina. (CatalogoDigital.SantaFelaVieja(1572-1660)

BienesAerqueologocosdelDepartamentodeEstudiosEtnograficosyColonialesdelaProvinciadeSantaFe, Argentina, 2009; htt://www2.ceride.gov.ar/whis/etnografico/collecciones_arqueologicas/Metal_indumentaria.htm)

\section{Conclusion}

The considered material finds a wide range of analogies in Eurasia's significant sites that have been determined by the process of intercultural interaction in late Middle Age. There were two principal trading ways (for the Middle Volga and Kama regions) with the West - the Southern Italic, Genoese (through the Crimea to the Don and Volga) and the Northern, including Hanseatic (the Baltic through the Moscow state). The belt set and other articles as the bell may have come to Toretskoe settlement by one of these ways, Hanseatic commercial stamps, Crimean coins and other imported things confirm such possibilities.

\section{Recommendations}

This article should be of interest to archaeologists and historians of international relations and Late Middle Ages material culture.

\section{Acknowledgements}

The work is performed according to the Russian Government Program of Competitive Growth of Kazan Federal University.

The research was accomplished with the financial support of the Russian Humanitarian Science Foundation within the framework of the Project No.12-01-00096 "Material Culture of Toretskoe Trade-Handicraft settlement of the 15 th century.

I would like to thank the head of excavations in Bolgar, V.Koval for the opportunity to familiarize myself with the material.

I thank S. Bocharov for the announcement about the discovery of the bell.

I am grateful to A. Trifanov for performing electronic microscope analysis.

\section{References}

Adaksina, S. B., Kirilko, V. P., \& Mytz, V. L. (2004). Report on the Archaeological Exploration of the Medieval Fortress Chembalo (Balaklava) in 2003, Saint-Petersburg, Simferopol.

AnadoluMedeniyetlery, Selguklu. (1983). Osmanli.Istanbul,. III.

Anatolian Civilisations. (1983). Vol. III, Istanbul. 
Archaeological monuments Basin Cheremshan. (1990). Kazan.

Atanasov, G. G. (2011). Two Belts from $14^{\text {th }}$ Century Male Burials in Drastar (now Silistra, NE Bulgaria). In ArchaeologiaBulgarica, (XV, 2, pp.91-101). Sofija.

Barnea, P., \& Reaboi, T. (1998). Investigatilearheologice din OrheiulVechi in anul 19872 ( pp.151-159).

Buljevic, Z., Ivcevic, S., Mardesic, L., \& Visic-Ljubic, E. (1995). Salona Christiana. Arheoloskimuzej, Split.

Catalogo Digital.Santa Fe la Vieja(1572-1660). (2013, 1 сентября). Bienes Aerqueologocos del Departamento de Estudios Etnograficos y Coloniales de la Provincia de Santa Fe, Argentina,2009; htt://www2.ceride.gov.ar/whis/etnografico/collecciones_arqueologicas/Metal_indumentaria.htm (2013, 1 сентября)

Fakhrutdinov, R. G. (1975). Archaeological monuments Volga-Kama Bulgaria and its territory. Kazan.

Fingerlin, I. (1971). Gurtel des hohen und spatenMittelalters.

Gorelik, M. V. (2008). Golden Horde's Objects and their Local Analogies in Materials of Ancient Russian Cities. In Brief Reports of the Institute of Archaeology (Vol. 222, pp. 117-125). Moscow.

Koroleva, E. V. (1996). Results of Spectral Analysis of the Medieval Pskov Jewelry, in Archaeological Study of Pskov. Explorations in the Ancient Part of the Middle Town (1967-1991). Materials and Research Projects, Pskov, (Issue 3, Vol.1, pp.229-300). Pskov.

Kramarovsky, M. G. (1985). Silver of Levant and Artistic Metal of the Northern Black Sea Region of XIII-XV Centuries (on materials of Crimea and the Caucasus).Artistic Memorials and Problems of Oriental Culture. In Collection of Articles (pp.152-180). State Hermitage, Leningrade.

Kramarovsky, M. G. (2001). Treasures of the Golden Horde: Exhibition Catalogue,j.s.c. Slavia, Saint-Petersburg.

Kramarovsky, M. G., \& Gukin, V. D. ( 2006). Settlement Bokatash II (Results of Field Explorations of the Golden Horde Archaeological Expedition of the State Hermitage in 2004). State Hermitage, Saint-Petersburg.

Kramarovsky, M. G., \& Gukin, V. D. (2004). Settlement Bokatash II (Results of Field Explorations of the Golden Horde Archaeological Expedition of the State Hermitage in 2001-2003). Saint-Petersburg.

Lango, P., \& Polgar, S. (2009). Notes on Finds under Reg. No. 40.10 in the Dumbarton Oaks Byzantine Collection (USA), in Golden Horde's Heritage.Materials of International Conference "Political and Social-Economic History of the Golden Horde (XIII-XV cc.). Kazan, March 17, 2009. (Issue 1. pp.488-500). Kazan.

Malm, V. A. (1989). Simferopol Treasure Trove.Catalogue of the State Historical Museum. Moscow.

Otroshenko, V. V., \& Rassamakin, Yu. Ya. (1986). Polovets Complex of Chingulsk Kurgan.

Parani, M. G. (2003). Reconstructing the Reality of Images. Leiden.

Pavlova, V. (2011). XIV ${ }^{\text {th }}$ century Belt discovered near the village of Kichevo, Varna region. In Acta Musei Varnaensis. VIII-1, Terra Antigua Balcanica et Mediterranea, Varna (VIII-1, pp.461-479). Varna.

Polyakova, G. F. (1996). Products Made of Nonferrous and Precious Metals. In City of Bulgar. Craft of Metallurgists, Blacksmiths, and Casters (pp. 154-268). Kazan.

Povetkin, V. I. (2008). Sleigh-bells and Bells Among Other Noise-Producing and Percussion Devices in Daily Use of Ancient Novgorod Citizens. In Novgorod Historical Collection (Issue 11). Saint-Petersburg.

Ross, M. S. with an addendum by S. A. Boyd, \& S. R. Zwirn. (2005). Catalogue of the Byzantine and Early Medieval Antiquities in the Dumbarton Oaks Collection. Volume Two: Jewerly, Enamels and Art of the Migration Period (2nd ed.). Washington DC.

Ryndina, N. V. (1963). Technology of Production of Novgorod Jewelers of X-XV cc. In New Methods in Archaeology, Materials and Research in the USSR Archaeology (No.117). Moscow.

Schick, M. (2006).The sleigh bell finds from Gnalic wreck. In The Heritage of the Serenissima (pp.110-112). Koper.

Spindler, K. (2003). Mittelalter-und Neuzeitarchaologie in Forschung und Lehrean der UniversitatInsbruck. Archaeologie Osterreichs13 Sonderausgabe, 2002, NearchosSonderheft 8.

Valiulina, S. I. (2001). Report on Excavations in the Toretskoe Settlement in the Alekseyevsky District of the 
Republic of Tatarstan in 1998-1999. In Archive of the Archaeological Museum of Kazan Federal University. Kazan.

Valiulina, S. I. (2010). International Contacts of the early Kazan Khanate on Materials of the Toretskoe Settlement. In Russia and East in IX-XVI centuries (pp.183-191). Nauka, Moscow.

Valiulina, S. I. (2011). Material Culture of the early Kazan Khanate on the Results of exploration of the Toretskoe Settlement. In Proceedings II (XVIII) of the All-Russia Archaeological Congress in Suzdal (Vol. IV, pp.118-123). Institute of Archaeology of the Russian Academy of Sciences, Moscow.

Valiulina, S. I., \& Zaitseva, I. E. (2011). On the Issue of Nonferrous Metallurgy in the Toretskoe Settlement in the XV Century. In Dialogue of Urban and Steppe Cultures on the Eurasian Area, in Proceedings of the $V$ International Conference Devoted to the memory of G.A.Fedorov-Davydov, October 2-6, 2011 (pp. 281-287). Kazan, Astrakhan. Veselovsky, N.I. (1898). Exploration of the Group of Kurgans near the Belorechenskaya Cossack Village.In Reports of Archaeological Commission for the Year of 1896, Saint-Petersburg.

Zykov, A. P., \& Koksharov, S. F. (2001). AncientEmder. Ekaterinburg.

\section{Copyrights}

Copyright for this article is retained by the author(s), with first publication rights granted to the journal.

This is an open-access article distributed under the terms and conditions of the Creative Commons Attribution license (http://creativecommons.org/licenses/by/3.0/). 